\title{
RECENT DEVELOPMENTS IN INTERNATIONAL COMMERCIAL ARBITRATION
}

\author{
Houston Putnam Lowry*
}

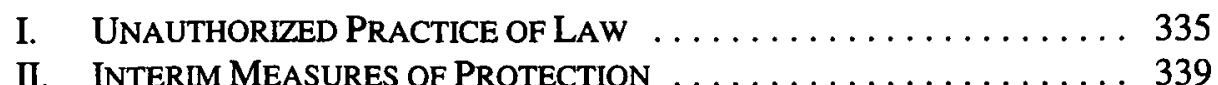

Arbitration is the preferred method of settling commercial disputes internationally. While there are many reasons, a large body of practice and law provide a certainty and finality that are missing even in transnational judicial determinations. The United States is not a party to any treaty on the enforcement of judgments. Not only is the United States not a party to any multilateral convention on the enforcement of judgments, it is not even a party to any bilateral convention on the enforcement of judgments.

There have been two major developments concerning international commercial arbitration over the past year. The first concerns the unauthorized practice of law and the second concerns interim measures of protection.

\section{UNAUTHORIZED PRACTICE OF LAW ${ }^{1}$}

This issue first arose in Hong Kong in the late 1980s. The outcry was so strong that Hong Kong felt it necessary to "clarify" that non-Hong Kong counsel could appear in Hong Kong arbitrations. ${ }^{2}$

A number of United States jurisdictions had considered whether or not appearing as an agent for a party in an arbitration (usually a domestic arbitration) constituted the practice of law. The older the case was, the more likely the jurisdiction would find it did not constitute the practice of law.

This issue was first considered in the United States Court of Appeals for the DC Circuit. ${ }^{3}$ The District of Columbia Motor Club (actually a Connecticut corporation) was the local representative of the American Automobile

* Member, Brown \& Welsh, P.C. of Meriden, Connecticut-http://brownwelsh.com; Chartered Arbitrator, Chartered Institute of Arbitrators (London)-http:/www.arbitrators.org; Freeman, Worshipful Company of Arbitrators (London)-http:/www.arbitratorscompany.org; Co-Chair ABILA International Commercial Law Committee. Email: HPLowry@BrownWelsh.com.

1. After this article was written, the Illinois Appellate Court ruled that representing a party to an arbitration does not constitute the practice of law. Colmar, Ltd. v. Fremantlemedia N. America, Inc., 801 N.E.2d 1017 (IIl. App. 2d 2003).

2. David St. John Sutton, The UNCITRAL Model Law: An Australian Perspective, 6 ARB. INT'L 348-59 (1990).

3. Am. Auto. Assoc. v. Merrick, 117 F.2d 23 (D.C. Cir. 1940). 
Association. ${ }^{4}$ As part of their membership services to some 29,000 local members, the motor club attempted to do two things: to amicably adjust claims for property damage to automobiles for or against a member where the amount in controversy does not exceed $\$ 100$; and to resolve such claims by arbitration if two members were involved. ${ }^{5}$

Members "consulted" a layman at the Motor Club concerning claims for damages to their automobiles sustained in accidents. ${ }^{6}$ If the member so requested, the Motor Club endeavored to collect the claim by writing to the other person involved in the accident, stating the amount of damages, presenting the claim, and requesting an answer relative to adjustment, or else the name of the insurance carrier. If no response is received, the Motor Club sends a followup letter concluding as follows:

Unless we hear from you within the coming week, we shall be obliged to advise our member that apparently no amicable settlement can be made of this matter, and to place the case in the hands of his counsel. We trust that such action will not be necessary, and that the matter may be amicably adjusted. ${ }^{7}$

If a response is received, the Motor Club will discuss the accident either with the third person or with his insurer. "Such discussion includes such subjects as right of way, provisions of traffic regulations, who is at fault, contributory negligence . . . and the like." If a settlement is made, the Motor Club's employee fills out release forms for signature of the proper party. ${ }^{10}$

If no amicable settlement can be reached, the member is so informed and advised to get his own attorney or to proceed in the small claims court. "If two members of the Motor Club are involved in the same accident and consult the Motor Club, the two claims are submitted to arbitration. ${ }^{12}$

The local bar association brought suit to enjoin this unauthorized practice of law. ${ }^{13}$ While the appellate court agreed there was an authorized practice of law, the court noted that simply representing a party to an arbitration did not constitute the practice of law. ${ }^{14}$
4. Id. at 23 .
5. Id.
6. Id. at 24 .
7. Id.
8. Am. Auto. Assoc., 117 F.2d at 24.
9. Id.
10. Id.
11. Id.
12. Id.
13. Am.. Auto. Assoc., 117 F.2d at 23.
14. Id. at 25 . 
Williamson v. John D. Quinn was cited with approval in a study by the Association of the Bar of the City of New York that representing a party in an arbitration did not constitute the unauthorized practice of law. ${ }^{15}$ The court mentioned a number of factors in its decision that representing a party to an arbitration does not constitute the practice of law:

1. An arbitration record is less complete than a court record.

2. The rules of evidence do not apply.

3. The usual court procedures common to civil trials (such as discovery) are absent or curtailed.

4. The procedure is informal.

This case was cited with approval in another federal case where an attorney not admitted in New York (but who had a New York office) was allowed to cover attorneys' fees for an arbitration conducted in Mexico City. ${ }^{16}$ New York law seems fairly clear: a foreign lawyer may represent a party in an arbitration. ${ }^{17}$ Regrettably, this marked the high water point of this school of thought.

In a case that received much attention at the time, California held that representing a party to an arbitration constituted the practice of law. ${ }^{18}$ This case arose in the context of a legal malpractice action and prevented a law firm from recovering fees for substantial work performed in connection with an arbitration to be held in California. California then adopted a procedure to allow out-ofstate counsel (but only from the United States) to easily obtain permission to represent a party to an arbitration. ${ }^{19}$ Counsel from other countries still may not represent clients in arbitrations held in California. ${ }^{20}$

The Arizona Supreme Court then held that representing a party to an arbitration constituted the practice of law. ${ }^{21}$ Arizona defines the practice of law as:

those acts, whether performed in court or in the law office, which lawyers customarily have carried on from day to day through the centuries constitute the practice of law. Such acts ... include rendering to another any other advice or services which are and have been

15. 537 F. Supp. 613, 618 (S.D.N.Y. 1982).

16. Siegel v. Bridas Sociedad Anonima Petrolera Industrial y Comercial, 1991 U.S. Dist. LEXIS 11455 , at * 17 (S.D.N.Y. 1991).

17. Id.

18. Birdbrower, Montalbano, Condon \& Frank, P.C. v. Super. Ct. of Santa Clara County, 949 P.2d 1, 9 (Cal. 1998).

19. Id. at 7, citing CAL. CT. R. 983.4.

20. Id.

21. In re Frederick C. Creasy, Jr., 12 P.3d 214, 219 (Ariz. 2000). 
customarily given and performed from day to day in the ordinary practice of members of the legal profession. ${ }^{22}$

Given the fact Creasy was a disbarred lawyer, the Arizona Supreme Court found conducting a cross-examination during an arbitration clearly constituted the unauthorized practice of law and violated their disbarment order. ${ }^{23}$

The next case where representing a party was held to constitute the practice of law was The Florida Bar v. Rapoport. ${ }^{24}$ Rapoport was a member in good standing of the District of Columbia Bar and represented a variety of clients in federal securities arbitrations (and advertised for such cases in Florida newspapers). ${ }^{25}$ Ruling that Florida Bar re Advisory Opinion on Nonlawyer Representation, ${ }^{26}$ was directly on point, the Florida Supreme Court ruled that Rapoport was not authorized to represent clients in securities arbitrations within Florida. ${ }^{27}$

The Connecticut Bar Association's Unauthorized Practice of law committee recently issued informal opinion 2002-02, holding that it would be an unauthorized practice of law for an attorney admitted only in New York to represent a party to a domestic arbitration held within Connecticut. ${ }^{28}$ However, a statute mandates the opposite conclusion concerning international arbitrations -representing a party to an international arbitration does not constitute the practice of law within Connecticut. ${ }^{29}$

With this background, foreign counsel will have to be careful about appearing in arbitrations within the United States even if local counsel is employed. Very often unauthorized practice of law statutes are criminal statutes that can have very unfortunate effects.

22. Id. at 217.

23. Id.

24. 845 So. $2 d 874$ (Fla. 2003).

25. Id. at 875 .

26. The Florida Bar re: Advisory Opinion-Nonlawyer Representation Sec. Arbitration, 696 So.2d 1178 (Fla. 1997).

27. Id. at 877 .

28. Conn. Bar Ass'n. Informal Op. 2002-02 (2002), available at http://brownwelsh.com/Archive/CBA_arbitration_ethical_opinion.pdf. (last visited Mar. 20, 2004).

29. CONN. GEN. STAT. \$§ 51-88 (2003).

The provisions of this section shall not be construed as prohibiting: (1) A town clerk from preparing or drawing deeds, mortgages, releases, certificates of change of name and trade name certificates which are to be recorded or filed in the town clerk's office in the town in which the town clerk holds office; (2) any person from practicing law or pleading at the bar of any court of this state in his own cause; or (3) any person from acting as an agent or representative for a party in an international arbitration as defined in subsection (3) of section 50a-101. 


\section{INTERIM MEASURES OF PROTECTION}

Arbitration awards are generally enforced under the 1958 New York Convention on The Recognition and Enforcement of Foreign Arbitral Awards. ${ }^{30}$ For arbitral awards under Inter-American system, the enforcement mechanism can be found in the 1975 Panama Inter-American Convention on International Commercial Arbitration. ${ }^{31}$ Each of these two conventions also provides a mechanism for enforcing agreements to arbitrate. Similar mechanisms are found in UNCITRAL's 1985 Model Law on International Commercial Arbitration. ${ }^{32}$ However, none of these legal documents provide a mechanism for enforcing interim measures of protection (sometimes called "IMPs").

The arbitration rules promulgated by the American Arbitration Association's International Centre for Dispute Resolution, ${ }^{33}$ the International Chamber of Commerce, ${ }^{34}$ the London Court of International Arbitration, ${ }^{35}$ and Chicago International Dispute Resolution Association, ${ }^{36}$ and UNCITRAL's ad hoc rules $^{37}$ all provide for interim measures of protection. Everyone is certain the arbitral tribunal may issue such orders, but no one has described what they are in any detail, the circumstances for their issuance, or how they are to be enforced.

30. As of Nov. 3, 2003, 134 countries were parties to this convention. See Status of Conventions and Model Laws, available at http://www.uncitral.org/english/starus/status-e.htm (last visited Feb. 29, 2004).

31. See generally Inter-American Convention on International Commercial Arbitration, Jan. 30 , 1975, 14 I.L.M. 336 (1975), available at http:/www.oas.org/juridico/english/treaties/b-35.htm (last visited Feb. 26, 2004). The current parties are: Arg., Bol., Braz., Chile, Colom., Costa Rica, Ecuador, El Sal., Guat., Hond., Mex., Nicar., Pan., Para., Peru, U.S., Uru, and Venez.

32. See generally Model Law on International Commercial Arbitration, UNCITRAL, Annex I, U.N. Doc. A/40/17 (1985), available at http://www.uncitral.org/english/texts/arbitration/ml-arb.htm (last visited Feb. 26, 2004).

33. See generally AM. ARBITRation ASs'N, INT'L DisPute Resolution Procedures (2003), available t $\mathrm{http}: / / \mathrm{www}$. adr.org/index2.1.jsp?JSPssid=15747\&JSPsrc=upload/LIVESITERules_Proceduresi National_International..l.lfocusArealinternational AAA175current.htm (last visited Feb. 29, 2004).

34. See generally INT'L CHAMBER OF COMMERCE, RULES OF ARBITRATION (1998), available at http://www.iccwbo.org/court/english/arbitration/rules.asp (last visited Feb. 26, 2004).

35. See generally THE LONDON COURT OF INT'L ARBITRATION, ARBITRATION; RULES, Clauses \& COSTS (1998), available at hitp://www.lcia-arbitration.com/town/square/xvc24/arb/uk.htm (last visited Feb. 29, 2004).

36. See generally Chicago INT'L Dispute Resolution Ass'N, THE ARBITRATION RULES OF CHICAGO INT'L DISPUTE RESOLUTION ASS'N (1999), available at http://cidra.org/rules.htm (last visited Feb. 26, 2004).

37. See generally G.A. Res 31/98, UNCITRAL, 31st Sess., Supp. No. 17, chap V, sect. C, U.N. Doc.A/31/17(1976), available at http://www.uncitral.org/english/texts/arbitration/arb-rules.htm (last visited Feb. 26, 2004). 
There are several different categories of interim measures of protection:

1. Preservation of evidence.

2. Preserving the status quo while the arbitration proceeds.

3. Ensuring the ultimate award will be effective (commonly called a prejudgment remedy in the domestic context).

While interim measures of protection are more commonly used in commercial arbitration, they are generally applicable to any kind of arbitration. In each and every commercial dispute, there is a concern about whether or not the ultimate judgment will be paid. In each and every arbitration, there are two parties to the transaction that cannot be parties to the arbitration: the taxman and the bankruptcy trustee.

It is hornbook law that third parties cannot be bound by an arbitrator's decision. This means an interim measure of protection issued by an arbitral tribunal (without more) is often useless (especially against the taxman and the bankruptcy trustee).

The procedure for issuing an interim order of protection under the American Arbitration Association rules, International Chamber of Commerce rules, London Court of International Arbitration rules, and the Chicago International Dispute Resolution Association rules is not clear. Whether or not interim measures of protection can be used to secure future arbitration awards is unclear. The only clear point is the arbitral tribunal may issue interim measures of protection.

The standards for judicially issued prejudgment remedies vary from court to court, even in the United States. Some legal systems require only probable cause. $^{38}$ Some legal systems require exigent circumstances. Judicial prejudgment remedies are not entitled to full faith and credit recognition even within the United States, suggesting they will be even more difficult to enforce internationally than judgments.

Even if an arbitral tribunal issues an interim measure of protection, it is uncertain if a court will enforce it or how a court should enforce it. It is even uncertain how the arbitral body itself will enforce it. The dividing line between court order and arbitral tribunal ordered interim measures of protection is not clear even in the 1985 UNCITRAL Model Law. ${ }^{39}$

Recognizing the importance of this topic, UNCITRAL has begun deliberating. At the present time, it is unclear what UNCITRAL is actually deliberating. Only after the final text is concluded is it likely that the parties

38. See e.g., CONN. Gen. STAT. \$§ 52-278 (2003).

39. Compare UNCITRAL Model Law, supra note 36, at art. 9, with UNCITRAL Model Law, id., at art. 17. 
will have decided if this will be an amendment to the 1958 New York Convention, ${ }^{40}$ an interpretive document for the 1958 Convention $^{41}$ or an amendment to the UNCITRAL Model Law.

UNCITRAL has been working from the following text: ${ }^{42}$

Enforcement of interim measures of protection

(1) Upon an application by an interested party, made with the approval of the arbitral tribunal, the competent court shall refuse to recognize and enforce an interim measure of protection referred to in article 17 , irrespective of the country in which it was ordered, if:

(a) The party against whom the measure is invoked furnishes proof that:

(i) [Variant 1$]$ The arbitration agreement referred to in article 7 is not valid

[Variant 2] The arbitration agreement referred to in article 7 appears to not be valid, in which case the court may refer the issue of the [jurisdiction of the arbitral tribunal] [validity of the arbitration agreement] to be decided by the arbitral tribunal in accordance with article 16 of this Law;

(ii) The party against whom the interim measure is invoked was not given proper notice of the appointment of an arbitrator or of the arbitral proceedings [in which case the court may suspend the enforcement proceedings until the parties have been heard by the arbitral tribunal]; or

(iii) The party against whom the interim measure is invoked was unable to present its case with respect to the interim measure [in which case the court may suspend the enforcement proceedings until the parties have been heard by the arbitral tribunal]; or

40. This will undoubtedly create some transition issues between states that adopt the amendment and states that do not.

41. This document would be effective immediately and would not require any action on the part of the present States Parties to adopt it. However, these is some question of how far a new concept may be placed in an old document before it becomes clear to everyone the "interpretation" is really a disguised amendment.

42. Report of the Working Group on Arbitration on the Work of Its Thirty-Eighth Session, UNCITRAL, 36th Sess., Agenda Item 3, U.N. Doc. A/CN.9/524 (2003), available at http://www.uncitral.org/english/sessions/unc/unc-36/acn9-524-e.pdf (last visited Feb. 29, 2004) [hereinafter Report of the Working Group]. 
(iv) The interim measure has been terminated, suspended or amended by the arbitral tribunal;

(b) The court finds that:

(i) The measure requested is incompatible with the powers conferred upon the court by its procedural laws, unless the court decides to reformulate the measure to the extent necessary to adapt it to its own powers and procedures for the purpose of enforcing the measure; or

(ii) The recognition or enforcement of the interim measure would be contrary to the public policy of this State.

(2) Upon application by an interested party, made with the approval of the arbitral tribunal, the competent court may, in its discretion, refuse to recognize and enforce an interim measure of protection referred to in article 17, irrespective of the country in which it was ordered, if the party against whom the measure is invoked furnishes proof that application for the same or similar interim measure has been made to a court in this State, regardless of whether the court has taken a decision on the application.

(3) The party who is seeking enforcement of an interim measure shall promptly inform the court of any termination, suspension, or amendment of that measure.

(4) In reformulating the measure under paragraph (1) (b)(i), the court shall not modify the substance of the interim measure.

(5) Paragraph (1) (a)(iii) does not apply

[Variant 1] to an interim measure of protection that was ordered without notice to the party against whom the measure is invoked provided that the measure was ordered to be effective for a period not exceeding [30] days and the enforcement of the measure is requested before the expiry of that period.

[Variant 2] to an interim measure of protection that was ordered without notice to the party against whom the measure is invoked provided that such interim measure is confirmed by the arbitral tribunal after the other party has been able to present its case with respect to the interim measure.

[Variant 3] if the arbitral tribunal, in its discretion, determines that, in light of the circumstances referred to in article 17 (2), the interim measure of protection can be effective only if the enforcement 
order is issued by the court without notice to the party against whom the measure is invoked."

The casual reader should remember first drafts are never quite as good as final drafts. Undoubtedly the negative pregnant of the first section of this draft will be fixed before it reaches its final form.

The first feature of section 1 is the requirement the arbitral tribunal must "approve" the application for interim measures of protection. The concept of allowing the arbitral tribunal to consider the question of interim measures of protection before a court seems appropriate, as long as the arbitral tribunal has been established. A request for interim measures of protection should not be denied or delayed simply because the arbitral tribunal had not been appointed yet.

The latter part of section 1 refers to recognizing and enforcing an interim measure of protection. This suggests the arbitral tribunal has actually issued an order for an interim measure of protection. But what happens if the tribunal orders an interim measure of protection but does not approve the application to the court to confirm it? Does this deprive the court of jurisdiction? Apparently it does under this draft.

Why should there be a two-step process when a single step would be preferable? The simplest procedure should be preferred to promote the economical enforcement of interim measures of protection ordered by arbitral tribunals. If an arbitral tribunal orders an interim measure of protection, it should be assumed the tribunal has no objection to a court enforcing that order. If the tribunal objects to a court enforcing the order, the tribunal may terminate, suspend or amend its order at any time.

It should be noted that the application to enforce can be made to the court by any "interested party." Presumably this definition is somewhat broader than simply a "party" to the arbitration. It seems possible a third party may try to enforce an interim measure of protection under some very rare circumstances. ${ }^{43}$

Under certain circumstances, an interim measure of protection should not be enforced. The first is when the arbitral tribunal has no jurisdiction. Lacking jurisdiction, the tribunal should not have issued the order in the first place. The question is who should determine the jurisdiction of the arbitral tribunal.

Under international arbitration, the doctrine of "competence-competence" receives great support. The arbitral tribunal has the competence to determine its own jurisdiction. This means variant 2 of subsection 2 will undoubtedly receive a great deal of support.

The next major area of concern is the level of due process afforded the defendant (although an interim measure of protection could be awarded against

43. Possibly a third party stakeholder might in the context of an interpleader. 
a plaintiff). If a party is not afforded an opportunity to present its case (because it was issued ex-parte improperly ${ }^{44}$ or was not aware the tribunal had been appointed ${ }^{45}$ ), the interim measure of protection should not be enforced. Under such circumstances, the matter should be referred back to the arbitral tribunal for further proceedings.

There is a further level of inquiry under section 5 about the arbitral tribunal's authority to issue ex-parte interim measures of protection. Virtually everyone agrees interim measures of protection should be able to issue ex-parte orders of interim protection. The question is under what circumstances are $e x$ parte orders appropriate. The three variants under section 5 try to provide that guidance. Time will tell which one is adopted.

A court should not enforce an interim measure of protection if it is not within the power of the court. ${ }^{46}$ If the court feels it can do so, the court may reform the interim measure of protection so it will (i) conform to its own procedural laws and (ii) not violate the enforcing court's state's public policy. ${ }^{47}$ Such a reformation should not change the essential substance of the arbitral tribunal's order. ${ }^{48}$

In short, UNCITRAL's initial draft is a good attempt to modify the Model Law to show when (and how) a court should enforce an interim measure of protection order by a tribunal. While it is far from perfect, it will provide the courts with explicit guidance on how they should evaluate requests to enforce interim measures. Once these legal issues are resolved, the number of applications to courts will undoubtedly increase.

44. Report of the Working Group, supra note 42, at 16.

45. Id. at 15 .

46. Id. at 17 .

47. Id.

48. Id. at 14 . 